\title{
Winter climate change promotes altered spring growing season in piñon pine-juniper woodlands
}

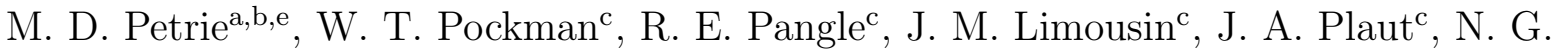 \\ McDowell $^{\mathrm{d}}$ \\ ${ }^{a}$ United States Geological Survey, Southwest Biological Science Center, Flagstaff AZ \\ ${ }^{b}$ Dept. of Botany, University of Wyoming, Laramie $W Y$ \\ ${ }^{c}$ Dept. of Biology, University of New Mexico, Albuquerque NM \\ ${ }^{d}$ Earth and Environmental Sciences Division, Los Alamos National Laboratory, Los Alamos, NM \\ ${ }^{e}$ Corresponding author, email:mpetrie@usgs.gov; Tel:1.505.453.4706; Fax:1.505.277.0304
}

\section{Abstract}

Piñon pine-juniper (Pinus edulis-Juniperus monosperma) woodlands constitute a large proportion of land area in the southwestern United States and have experienced widespread vegetation mortality during regional drought events over the past century. Piñon pines have been especially affected by these events, and drought severity is predicted to increase in this region in the future. Based on research that suggests winter climate may influence growing season productivity in semiarid ecosystems, we evaluated the potential for small changes in average winter climate to affect spring growing season conditions in piñon-juniper woodlands, New Mexico, USA. We developed a low-dimensional ecohydrological model of piñon-juniper woodland ecosystems on moderate slopes (5\%) and on steep slopes $(25 \%)$ and simulated the responses of ecosystem water availability, surface conditions, and water and carbon flux dynamics to a climate change scenario of increased temperature and decreased winter precipitation. The climate change scenario reduced average winter snowcover, decreased surface albedo, increased net radiation, and altered the timing of spring evaporation (E) towards earlier dates. Moderate slope piñon and juniper trees experienced small reductions in transpiration ( $\mathrm{Tr}$ ) and carbon assimilation (A), and those on steep slopes experienced small but relatively larger reductions in Tr and A, as well as higher increases in soil moisture $(\theta)$ variance and E variance. As a result of climate change, the peak of spring Tr occurred on average 6 days earlier on moderate 
slopes and 10 days earlier on steep slopes, the timing of A shifted towards earlier March dates, and A was reduced during April and May. Steep slope piñon pines experienced greater proportional reductions in Tr and A than junipers. Our results suggests that winter climate change will promote an earlier growing season in piñon-juniper woodlands, will increase daily variance in $\theta$ and $\mathrm{E}$ during spring, and will produce slight reductions in $\mathrm{A}$ in woodlands with steep slopes and a large proportion of piñon pines. In a more arid future climate, a shift towards lower soil moisture availability and carbon assimilation in April and May may intensify the effects of early summer drought events for piñon-juniper woodlands, thus exacerbating the impacts of larger changes in climate dynamics.

Keywords: climate change, winter ecology, southwestern United States, piñon-juniper woodland

\section{Introduction}

In the 21st century, increasing aridity produced by global climate change may have profound negative impacts on the viability of piñon pine (Pinus edulis) and juniper (Juniperus monosperma)-dominated woodlands across the southwestern United States. During the 20th century, regional drought events produced widespread tree mortality in these woodlands (Breshears et al., 2005; Allen et al., 2010), and future disturbance events are expected to continue to alter ecosystem structure and functioning, the timing and quality of ecosystem services, and land-atmosphere interactions in woodland and forest ecosystems across the western and southwestern US (Breshears et al., 2009; Allen et al., 2010; Royer et al., 2012). Indeed, the possibility of climate-induced changes in aridland ecosystem functioning may actually be increasing (Diffenbaugh et al., 2008; Williams et al., 2013), and these systems may have a disproportionate effect on terrestrial ecosystem services (Poulter et al., 2014). Climate change projections for the southwestern US are uncertain, but it is probable that the region will experience greater temperature-driven aridity (Seager et al., 2007; Notaro et al., 2012; Gutzler and Robbins, 2011), changes in the seasonal timing of rainfall (Seth et al., 2011; Seager and Vecchi, 2010), and possible 
reductions in rainfall in winter and summer (Weltzin et al., 2003; Gutzler and Robbins, 2011; Seager and Vecchi, 2010). Due to increasing temperature-driven aridity and greater rainfall variability, the type of deleterious drought events that have produced widespread forest deterioration in the 20th century are likely to persist and perhaps intensify (Breshears et al., 2005; Huxman et al., 2004; Williams et al., 2013).

Piñon-juniper woodlands are among the most sensitive southwestern US ecosystems to drought events, yet much of this is due to the high susceptibility of isohydric piñon pines to moisture limitation than it is to anisohydric junipers, which are less sensitive to both high and low moisture availability (Breshears et al., 2005, 2009; Shaw et al., 2005; Kleinman et al., 2012; Plaut et al., 2012; Limousin et al., 2013). The deleterious impacts of moisture limitation may be produced by even short-duration events - experimental research in piñon-juniper stands shows that extreme moisture limitation in a single year is sufficient to severely restrict gas exchange and hydraulic conductance in piñon pines and induce significant (67\%) mortality in already drought-stressed piñon trees (Plaut et al., 2012). Conversely, junipers experienced lower mortality and reduction in hydraulic conductance under the same environmental conditions (Plaut et al., 2012), and junipers are more capable than piñon pines of acclimating gas exchange to sustained moisture limitation on the order of 1-3 years (Limousin et al., 2013). Both species exhibit reduced transpiration response to pulses of moisture availability when they are drought stressed (Plaut et al., 2013), however, and we postulate that the altered timing or increased periodicity of soil moisture availability produced by climate change may have negative consequences for the structure and functioning of these ecosystems.

The extent to which small changes in climate may alter the structure and function of piñon-juniper ecosystems is not well understood. Increasing winter temperature as a result of climate change has led to earlier growing season onset in many North American ecosystems (Schwartz and Reiter, 2000; Schwartz et al., 2006), and an earlier spring may 
influence later-season resource availability and biophysical processes including soil moisture, evapotranspiration and vegetation carbon uptake in mesic and semiarid ecosystems Yu et al. (2003); Ryu et al. (2008); Petrie et al. (2012). The timing of resource availability is a critical component of growing season productivity in many woodland ecosystems (Royer et al., 2012), and changes to the timing of resource availability have seasonal and annual lag effects in many semiarid systems (Sala et al., 2012). Ladwig et al. (2015) found that variations in winter climate may impact growing season productivity in semiarid ecosystems, even those located in ecoregions without a prominent winter season. Although many piñon-juniper woodlands of the southwestern US do not normally experience snow accumulation during winter, increasing winter temperatures may still shift growing season onset towards earlier dates, as has been observed in snowmelt-sensitive forests (Baron et al., 2000; Brandes and Wilcox, 2000). We hypothesize that earlier onset of the spring growing season and the associated earlier use of available moisture may be the mechanism by which predicted small changes in winter climate in the southwestern US alter resource availability and vegetation exchanges of water and carbon later in the spring.

Incorporating the individual responses of piñon and juniper water and carbon exchanges in a modeling framework is a useful way to produce insight on the potential responses of piñon-juniper ecosystems to small changes in climate. One way to do this is by using low-dimensional modeling techniques, which are adept at characterizing ecosystem responses to driving climate variables in absence of extensive biophysical information. Low-dimensional ecological models have been used to explore linkages between precipitation and surface hydrology (Porporato et al., 2004; Daly and Porporato, 2005, 2006), to characterize ecosystem flux responses to variation in water availability (Makela et al., 1996; Laio et al., 2001; Porporato et al., 2003; Petrie and Brunsell, 2012), and to upscale vegetation data as a means to explore the responses of specific species and ecosystem types to external forcings (Ridolfi et al., 2000b; Porporato et al., 2001; Katul et al., 2007; Petrie et al., 2012). Patterns of water and carbon exchanges are a useful way 
to evaluate variation in ecosystem functioning, and have been used to explore ecological questions including the assessment of vegetation productivity (Huxman et al., 2004; Monson et al., 2005; Kurc and Small, 2007), identifying the consequences of land class change (Forzieri et al., 2011) and the quantification of land-atmosphere exchanges (Mendez-Barroso and Vivoni, 2010; Brunsell and Wilson, 2013; Royer et al., 2012). By using low-dimensional modeling techniques to characterize ecosystem and vegetation flux dynamics in piñon-juniper woodlands, it is therefore possible to explore the potential ecosystem response to winter climate change in a way that is complimentary to current scientific understanding of how these ecosystems function.

We hypothesized that winter climate change in piñon-juniper woodlands would alter the timing and magnitude of water availability, and thus reduce transpiration and carbon assimilation in piñon and juniper trees in spring. To explore the sensitivity of piñon-juniper woodlands to these changes, we developed a low-dimensional model of climate, ecology and surface hydrology of piñon-juniper woodlands in New Mexico, USA, and conducted simulations of winter climate change at these sites. Our primary objective was to determine if piñon-juniper woodlands are sensitive to small changes in average winter climate, and to also explore the possibility that Gutzler and Robbins (2011)'s predictions of increasing temperature $\left(+1.6^{\circ} \mathrm{C}\right)$ and slightly decreasing precipitation $\left(-0.11 \mathrm{~mm} \mathrm{month}{ }^{-1}\right)$ could shift the spring growing season towards earlier dates, and thus alter the timing and magnitude of spring water and carbon fluxes in piñon and juniper trees. In the event of more frequent and intense future summer drought events, we explored the possibility for winter climate change to pose an additional stress to forests and woodlands in the southwestern United States by reducing spring resource availability and vegetation carbon assimilation. The species-specific responses to climate change are not well documented in regional analyses of vegetation change and in Global Climate Model frameworks, and our study elucidates the impact that small changes in climate may have on these ecosystems in the 21st century as a means to better inform future research on these woodlands. 


\section{Site}

This study evaluated model simulations of changing winter climate forcings, surface hydrology and vegetation water and carbon flux dynamics for a piñon-juniper woodland located at the Sevilleta National Wildlife Refuge (SNWR), New Mexico, USA $\left(34.38^{\circ} \mathrm{N}\right.$, $106.57^{\circ} \mathrm{W}$; elevation $\left.=1911 \mathrm{~m}\right)$. This site was the location of a seven-year rainfall manipulation experiment in piñon-juniper woodland (Pangle et al., 2012). Annual total precipitation at this site is $363 \mathrm{~mm}$ (Pangle et al., 2012); approximately $45 \mathrm{~mm}$ of total precipitation occurs during winter (12.4\%, December-February) and $55 \mathrm{~mm}$ occurs during spring (15.2\%, March-May). Winter precipitation may occur as both snowfall or rainfall, and high solar radiation at the SNWR minimizes surface snow accumulation in winter. The density of piñon and juniper trees is lower at the SNWR than at other western US locations (Romme et al., 2009) - at the SNWR, piñon canopy coverage is $5.4 \%$ and juniper canopy coverage is $31.3 \%$. Soils at moderate slope sites are primarily Sedillo-Clovis gravelly sandy clay loam, 1-6\% slopes, and steep slope sites are primarily Puertecito very channery clay loam, 15-60\% slopes (United States Department of Agriculture, 2013). Active soil depth is $\sim 800 \mathrm{~mm}$ at sites with moderate slopes and $\sim 400 \mathrm{~mm}$ at sites with steep slopes, although there is variation in these values. Climate change projections for winter in the southwestern US call for slightly decreased winter precipitation $\left(-0.11 \mathrm{~mm} \mathrm{month}^{-1}\right)$ and increased daily temperature $\left(+1.6{ }^{\circ} \mathrm{C}\right)$ in the coming 50 years (Gutzler and Robbins, 2011).

\section{Methods}

Using a low-dimensional modeling framework, we explored the influence of changing climate forcings of decreased winter precipitation and increased daily average temperature on the functioning of piñon-juniper woodlands. We developed the model using ecohydrological modeling techniques (Laio et al., 2001; Porporato et al., 2001; Rodriguez-Iturbe and Porporato, 2004), models of snowmelt dynamics (Kustas et al., 1994), and calculations of solar radiation and potential evaporation (Dubayah, 1994; Milly, 1994; Campbell and Norman, 2008). Vegetation transpiration and carbon assimilation were 
trained in the model using data from a long-term experiment in piñon-juniper woodland at our study site (Pangle et al., 2012). The primary linkages in the model were between simulated climate forcings, soil moisture, evaporation and transpiration, and vegetation carbon assimilation. We implemented the model at the daily time step from December 1 to May 31 (182 day periods), with a prior 15 day spin up period corresponding to November 16 - 30. We did not simulate summer conditions, which are wetter than spring on average and would thus mask the effects of the climate change simulation. We simulated 2500 years (December-June) of daily rainfall and snowfall, soil moisture, evaporation, transpiration and carbon assimilation (Figure 1) for control and climate change scenarios at moderate (5\%) and steep (25\%) slopes (4 total scenarios with 2500 simulated years for each scenario).

All biophysical processes including snowmelt, soil evaporation, and piñon and juniper transpiration and carbon assimilation were incorporated into each simulated year. Soil parameters in the model were incorporated from Laio et al. (2001); Rodriguez-Iturbe and Porporato (2004)'s parametrizations for Loam and Sandy Loam soil, and we determined values for hydraulic conductivity $\left(\mathrm{K}_{s}\right)$, approximate soil active depth $(\mathrm{Zr})$ and maximum daily infiltration $\left(\mathrm{I}_{\max }\right.$ ) from the USDA soil survey database (United States Department of Agriculture, 2013) (Table 1). Steep slopes had lower active soil depth, lower soil infiltration capacity, and a higher slope than moderate slopes (Table 1). As a result of slope differences - both of which had a south-facing aspect - simulated net radiation, potential evaporation and mean temperature were higher on steep slopes compared to moderate slopes (Table 2). For the climate change scenario, we implemented 50-year projections (+50 y) for slightly lower winter precipitation $\left(-0.11 \mathrm{~mm} \mathrm{month}^{-1}\right)$ and higher average daily temperature $(+1.6$ ${ }^{\circ} \mathrm{C}$ ) in the southwestern United States from Gutzler and Robbins (2011) (Table 2). Mean daily model outputs (means of 2500 simulations) reflect the most probable daily value for each output variable (e.g. precipitation, soil moisture, water fluxes and vegetation carbon assimilation) in a single year, occurring 50 years in the future. 

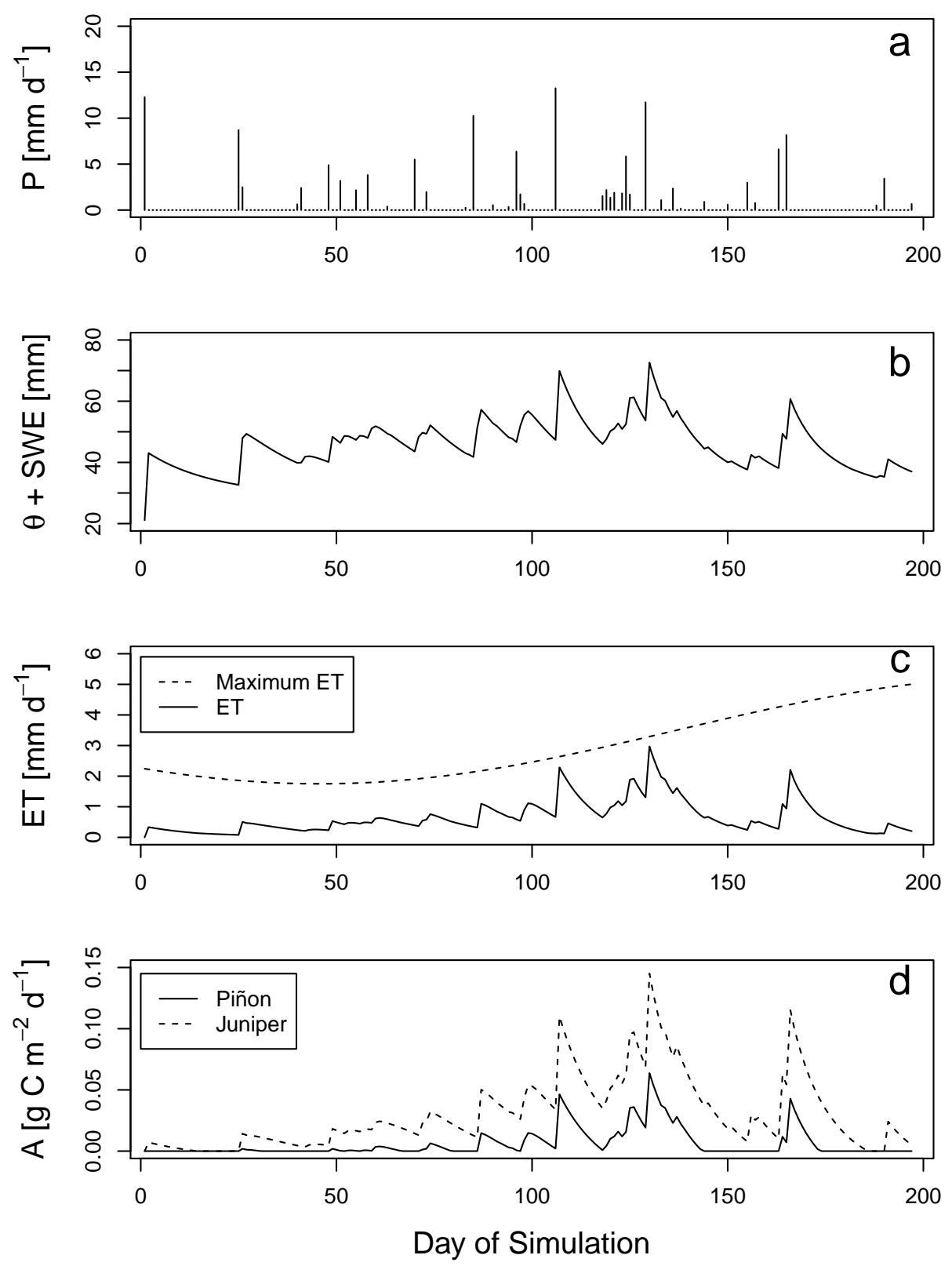

Figure 1: Model outputs of precipitation (Panel a), total moisture [ $\theta+$ SWE: mm] (Panel b), evaporation + transpiration $\left[\mathrm{ET}: \mathrm{mm} \mathrm{day}^{-1}\right]$ and potential evaporation [Ep: $\left.\mathrm{mm}^{\mathrm{day}}{ }^{-1}\right]$ (Panel c), and piñon and juniper carbon assimilation [A: $\mathrm{g} \mathrm{C} \mathrm{m}^{-2}$ day $\left.^{-1}\right]$ (Panel d) for one simulated season (November-June; 227 days). 
Table 1: Model constants, site and soil characteristics. Soil characteristics govern abiotic processes in the model.

\begin{tabular}{|c|c|c|c|c|}
\hline Variable & Name & $\begin{array}{c}\text { Moderate slope } \\
\text { value }\end{array}$ & $\begin{array}{l}\text { Steep slope } \\
\text { value }\end{array}$ & Units \\
\hline$\Psi_{s}$ & soil matric potential & $-7.0 \times 10^{-4}$ & $-7.0 \times 10^{-4}$ & $\mathrm{MPa}$ \\
\hline $\mathrm{K}_{s}$ & hydraulic conductivity & 500 & 500 & $\mathrm{~mm} \mathrm{day}^{-1}$ \\
\hline $\mathrm{b}$ & $\mathrm{n} / \mathrm{a}$ & 5.15 & 5.15 & $\mathrm{n} / \mathrm{a}$ \\
\hline c & $\mathrm{n} / \mathrm{a}$ & 13.3 & 13.3 & $\mathrm{n} / \mathrm{a}$ \\
\hline$\beta$ & $\mathrm{n} / \mathrm{a}$ & 14.3 & 14.3 & $\mathrm{n} / \mathrm{a}$ \\
\hline $\mathrm{n}$ & soil porosity & 0.44 & 0.44 & $\%$ \\
\hline $\mathrm{Zr}$ & active depth & 800 & 400 & $\mathrm{~mm}$ \\
\hline$\theta_{h}$ & soil hygroscopic point & 0.08 & 0.08 & $\%$ \\
\hline$\theta_{w}$ & soil wilting point & 0.16 & 0.16 & $\%$ \\
\hline$\theta^{*}$ & soil reduction point & 0.46 & 0.46 & $\%$ \\
\hline$\theta_{f c}$ & soil field capacity & 0.56 & 0.56 & $\%$ \\
\hline $\mathrm{I}_{\max }$ & maximum infiltration & 14.4 & 6.12 & $m m$ day $^{-1}$ \\
\hline $\mathrm{E}_{w}$ & evaporation at $S_{w}$ & 0.5 & 0.5 & $m m$ day $^{-1}$ \\
\hline $\mathrm{S}_{l}$ & slope & 5 & 25 & $\%$ \\
\hline $\mathrm{V}_{d}$ & sky view fraction & 0.8 & 0.8 & $\%$ \\
\hline Lat & latitude & 34.368 & 34.368 & ${ }^{\circ} \mathrm{N}$ \\
\hline ele & elevation & 1976 & 1976 & meters \\
\hline $\mathrm{t}$ & atmospheric transmittance & 0.85 & 0.85 & $\%$ \\
\hline $\mathrm{m}$ & optical air mass & 1.2 & 1.2 & $\%$ \\
\hline $\mathrm{S}_{p o}$ & extraterrestrial flux density & 1380 & 1380 & $\mathrm{~W} \mathrm{~m}^{-2}$ \\
\hline$\epsilon$ & atmospheric emissivity & 0.97 & 0.97 & $\%$ \\
\hline$\alpha_{s f c}$ & surface albedo & 0.2 & 0.2 & $\mathrm{n} / \mathrm{a}$ \\
\hline$\alpha_{\text {snow }}$ & maximum snow albedo & 0.9 & 0.9 & $\mathrm{n} / \mathrm{a}$ \\
\hline $\mathrm{SWE}_{\max }$ & maximum snow water equivalent & 300 & 300 & $\mathrm{~mm}$ \\
\hline
\end{tabular}




\subsection{Incorporation of experimental data}

We used field measurements of volumetric soil moisture $\left[\theta: \mathrm{mm}^{3} \mathrm{~mm}^{-3}\right]$, soil water potential $\left[\psi_{s}: \mathrm{MPa}\right]$, sapflow $\left[\mathrm{J}_{s}\right]$, and leaf gas exchanges of water $\left[\mathrm{g}_{s}: \mathrm{mmol} \mathrm{m}^{-2} \mathrm{~s}^{-1}\right]$ and carbon $\left[\mathrm{A}_{n}: \mu \mathrm{mol} \mathrm{m}{ }^{-2} \mathrm{~s}^{-1}\right]$ from a precipitation manipulation experiment in piñon-juniper woodland in central New Mexico, USA (Pangle et al., 2012) to constrain calculations of daily transpiration and carbon assimilation in piñon and juniper to daily fluctuations in $\theta$. $\theta$ was measured using EC-20 $\mathrm{ECH}_{2} \mathrm{O}$ probes (Decagon, Pullman, WA, USA) and compiled to daily averages from September, 2009 through December, 2012 (Pangle et al., 2012). $\psi_{s}$ was measured using PST-55 psychrometers (Wescor, Logan, UT, USA) and compiled to daily averages from December, 2007 to April, 2013 (Pangle et al., 2012). $J_{s}$ was measured using Granier sap-flow sensors from October, 2009 to April, 2013 and compiled to daily averages (Granier, 1987; Pangle et al., 2012). Leaf gas exchange was measured using portable gas exchange systems (LI-6400, Li-Cor Inc., Lincoln, NE, USA) in 2010 and 2011 and converted to water-use efficiency [WUE: $\mu$ mol C mmol $\mathrm{H}_{2} \mathrm{O}^{-1}$ ] (Limousin et al., 2013). The wilting point of piñon and juniper is actually lower than the soil hygroscopic point (0.08; Tables 1 and 3), which corresponds to the ability of many semiarid shrub and tree species to maintain sapflow $\left(\mathrm{J}_{s}\right)$ after bare soil evaporation has ceased by drawing moisture from deeper in the soil (Baldocchi and Xu, 2007; Cavanaugh et al., 2011; Plaut et al., 2013).

To model daily transpiration and carbon assimilation, we first estimated the relationship between $\theta$ and $\psi_{s}$ using data from September, 2009 through December, 2012 as:

$$
\psi_{s}=-4.96 \cdot e^{-16.31 \theta}
$$

We used this equation to estimate $\theta$ from December, 2007 through August, 2009 when $\theta$ data were not available but $\psi_{s}$ data were available, therefore increasing data availability to 5 years (2008-2012). This additional calculation improved the accuracy of our regression formulations for the relationships between $\theta$ and transpiration [Tr: $\mathrm{mm} \mathrm{m}^{-2}$ day $^{-1}$ ], and theta and carbon assimilation $\left[\mathrm{A}: \mathrm{g} \mathrm{C} \mathrm{m}^{-2} \mathrm{~d}^{-1}\right]$ for piñon pines and junipers. We estimated 
Table 2: Control and climate change $(+50$ y) simulations

\begin{tabular}{|c|c|c|c|c|}
\hline Variable & & Control & $+50 \mathrm{y}$ & Units \\
\hline $\mathrm{E}_{p 0}$, moderate & mean potential evaporation & 3.5 & 4.0 & $m m$ day $^{-1}$ \\
\hline $\mathrm{E}_{p 0}$, steep & & 4.4 & 5.0 & mm day ${ }^{-1}$ \\
\hline $\mathrm{T}_{a 0}$, moderate & mean air temperature & 12.7 & 14.3 & ${ }^{\circ} \mathrm{C}$ \\
\hline $\mathrm{T}_{a 0}$, steep & & 15.9 & 17.9 & ${ }^{\circ} \mathrm{C}$ \\
\hline \multirow[t]{6}{*}{$\lambda$} & December & 0.200 & 0.200 & events day $^{-1}$ \\
\hline & January & 0.179 & 0.179 & events day $^{-1}$ \\
\hline & February & 0.192 & 0.192 & events day $^{-1}$ \\
\hline & March & 0.192 & 0.192 & events day $^{-1}$ \\
\hline & April & 0.145 & 0.145 & events day $^{-1}$ \\
\hline & May & 0.150 & 0.150 & events day $^{-1}$ \\
\hline \multirow[t]{6}{*}{$\alpha$} & December & 3.22 & 3.20 & $\mathrm{~mm}$ event $^{-1}$ \\
\hline & January & 2.44 & 2.42 & $\mathrm{~mm}$ event $^{-1}$ \\
\hline & February & 2.98 & 2.96 & $\mathrm{~mm}$ event ${ }^{-1}$ \\
\hline & March & 4.14 & 4.12 & mm event ${ }^{-1}$ \\
\hline & April & 3.89 & 3.89 & $\mathrm{~mm}$ event $^{-1}$ \\
\hline & May & 3.90 & 3.90 & $\mathrm{~mm}$ event $^{-1}$ \\
\hline \multirow{4}{*}{$\begin{array}{c}\text { Snow Accumulation } \\
\text { Probability, moderate slope }\end{array}$} & December & 78 & 51 & $\%$ \\
\hline & January & 71 & 50 & $\%$ \\
\hline & February & 32 & 12 & $\%$ \\
\hline & March & 5 & 0 & $\%$ \\
\hline \multirow{4}{*}{$\begin{array}{c}\text { Snow Accumulation } \\
\text { Probability, steep slope }\end{array}$} & December & 3 & 0 & $\%$ \\
\hline & January & 6 & 0 & $\%$ \\
\hline & February & 0 & 0 & $\%$ \\
\hline & March & 0 & 0 & $\%$ \\
\hline
\end{tabular}


Table 3: Piñon pine and juniper characteristics, which govern biotic processes in the model.

\begin{tabular}{|c|l|ccc|}
\hline Variable & Name & Piñon & Juniper & Units \\
\hline $\operatorname{Tr}_{0}$ & mean potential transpiration & 10.58 & 8.7 & $\mathrm{~J}_{s}$ \\
$\theta_{w}$ & actual wilting point & 0.064 & 0.051 & $\%$ \\
$\theta^{*}$ & actual reduction point & 0.14 & 0.13 & $\%$ \\
- & cover & 0.054 & 0.313 & $\mathrm{~m}^{2} \mathrm{~m}^{-2}$ \\
- & sapwood area & $1.11 \times 10^{-4}$ & $2.28 \times 10^{-4}$ & $\mathrm{~m}^{2} \mathrm{~m}^{-2}$ \\
WUE $_{\text {slope }}$ & slope of $\theta$-water-use efficiency & -21.72 & -25.70 & - \\
WUE $_{y-\text { int }}$ & y intercept of $\theta$-WUE & 4.08 & 4.41 & - \\
$\theta_{\text {wuemax }}$ & n/a & 0.095 & 0.085 & $\%$ \\
WUE $_{\text {max }}$ & WUE at $\theta_{\text {wuemax }}$ & 1.91 & 2.10 & - \\
$\theta_{\text {wuemin }}$ & n/a & 0.065 & 0.05 & $\%$ \\
WUE $_{\text {min }}$ & WUE at $\theta_{\text {wuemin }}$ & 0 & 0 & - \\
\hline
\end{tabular}

the average relationship between $\theta$ and Tr using a linear regression equation, and we used field measurements of $\mathrm{J}_{s}$ and species sapwood area at the plot level to calculate daily $\mathrm{Tr}$ for the regression analysis (Table 3, Figure 2c). We modeled A for piñon pines and junipers using field measurements of gas exchange, scaled to the plot level (Figure 2d).

\subsection{Precipitation, snowfall and water balance}

We generated precipitation in the model using a Poisson process of event timing $[\lambda$ : events day $\left.^{-1}\right]$ and magnitude $\left[\alpha: m m\right.$ event $\left.^{-1}\right]$, where daily precipitation was generated using a Monte Carlo simulation (D'Odorico et al., 2000). Monthly values of $\lambda$ and $\alpha$ were calculated using 1990-2010 data from a nearby meteorological station located at the SNWR [http://sev.lternet.edu/data/sev-1] and these values were implemented in the Poisson generation process (Table 2). Using SNWR temperature data from the same meteorological station, we estimated that snowfall accumulation is limited to days with mean daily air 

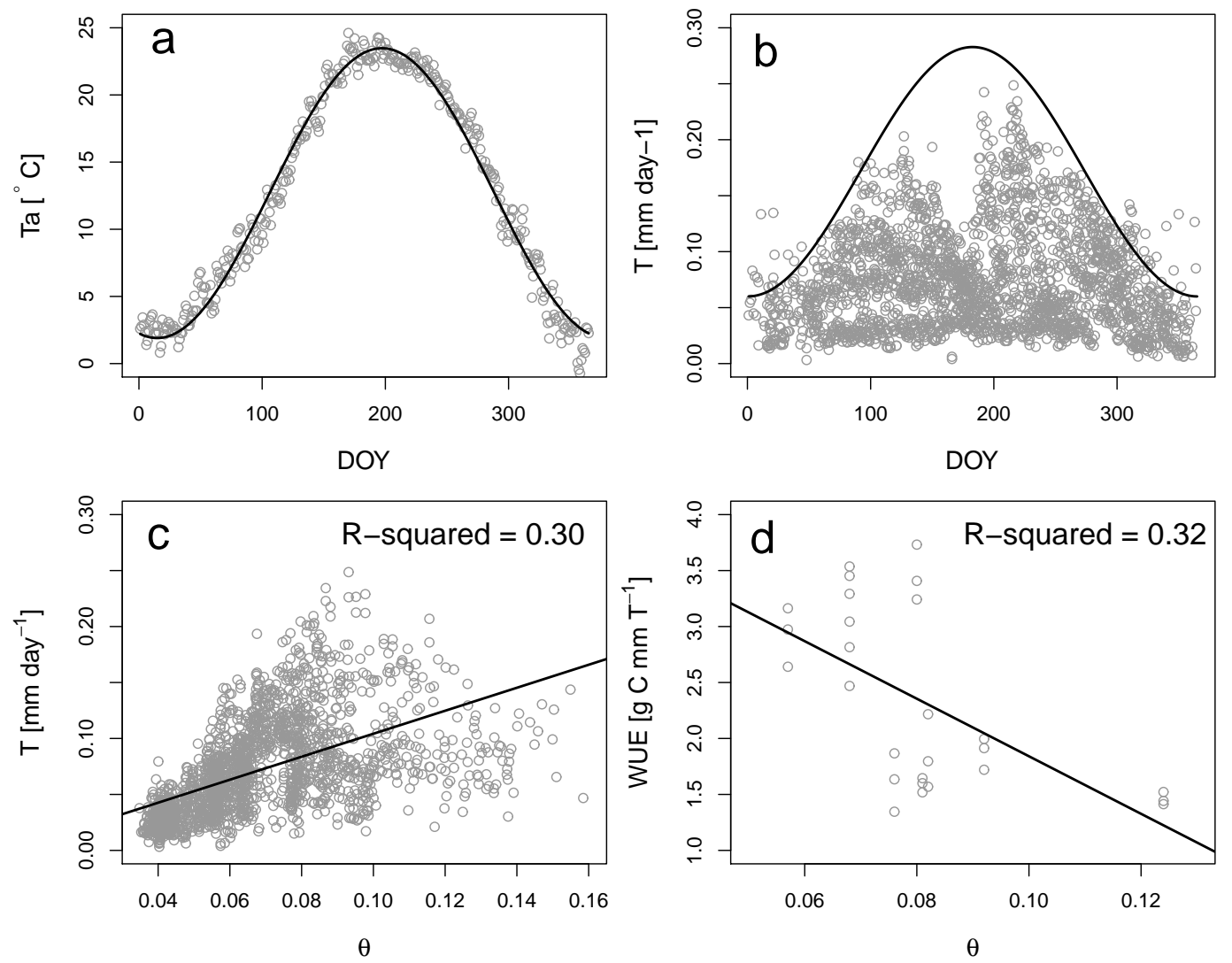

Figure 2: Modeled daily air temperature from temperature data $\left[\right.$ Ta: $\left.{ }^{\circ} \mathrm{C}\right]($ Panel a), example of modeled maximum transpiration from juniper transpiration data on moderate slopes [T: mm day ${ }^{-1}$ ] (Panel B), T- $\theta$ relationship for juniper trees on moderate slopes (Panel c), and water-use efficiency- $\theta$ [WUE: $\mathrm{g} \mathrm{C} \mathrm{mm}^{-1}$ ] relationship for juniper trees on moderate slopes. 
temperature $<2.5^{\circ} \mathrm{C}$. Therefore, the probability of snowfall versus rainfall in the model is the proportion of days per month where mean daily air temperature $<2.5^{\circ} \mathrm{C}$, based on 1990-2010 meteorological data (Table 2).

In the model, snowfall was stored in an aboveground snow-water equivalent $[S W E$ : mm] layer, which could be added to or melted in subsequent days, increasing $S W E$ or infiltrating SWE (as snowmelt) into the soil and increasing volumetric soil moisture $[\theta$ : $\mathrm{mm}^{3} \mathrm{~mm}^{-3}$, respectively. The model's daily water balance is:

$$
\theta_{n+1}+S W E_{n+1}=\theta+P+S_{m e l t}-E-T r-R-L+\Delta S W E
$$

where $P$ is precipitation as snow or rainfall $\left[\mathrm{mm} \mathrm{m}^{-2} \mathrm{~d}^{-1}\right], S_{\text {melt }}$ is infiltrating snowmelt $\left[\mathrm{mm} \mathrm{m}^{-2} \mathrm{~d}^{-1}\right], E$ is soil evaporation $\left[\mathrm{mm} \mathrm{m}^{-2} \mathrm{~d}^{-1}\right], \operatorname{Tr}$ is the combined transpiration from piñon and juniper trees $\left[\mathrm{mm} \mathrm{m}^{-2} \mathrm{~d}^{-1}\right], R$ is runoff $\left[\mathrm{mm} \mathrm{m}^{-2} \mathrm{~d}^{-1}\right]$ and $L$ is soil leakage $[\mathrm{mm}$ $\mathrm{m}^{-2} \mathrm{~d}^{-1}$ ] from (Ridolfi et al., 2000a). Runoff occurred on days when $P+S_{\text {melt }}>$ soil infiltration capacity (Table 1 ).

\subsection{Soil evaporation}

We calculated daily potential evaporation $\left[\mathrm{E}_{p}: \mathrm{mm} \mathrm{d}^{-1}\right]$ from Milly (1994) as:

$$
E_{p}=\frac{E_{p 0}}{n Z r} \cdot\left[1+\delta_{e t} \cdot \sin \left(\omega_{e t} \cdot h_{d a y}+\phi_{e t}\right)\right]
$$

where $E_{p 0}$ is mean annual $E_{p}, \mathrm{nZr}$ is the active soil depth $[\mathrm{mm}], \delta_{e t}$ is the amplitude about $\frac{E_{p 0}}{n Z r}, \omega_{e t}$ is the frequency of the sinusoid $\left[\mathrm{d}^{-1}\right], h_{d a y}$ is the hydrologic day, and $\phi_{e t}$ is the phase shift (Table 1). We calculated E in a piecewise manner from Laio et al. (2001) as: 


$$
\begin{aligned}
& \text { if } \quad \theta \leq \theta_{h} ; \quad E=0 \\
& \text { if } \quad \theta_{h}<\theta \leq \theta_{w} ; \quad E=E_{w} \cdot\left(\frac{\theta-\theta_{h}}{\theta_{w}-\theta_{h}}\right) \\
& \text { if } \quad \theta_{w}<\theta \leq \theta^{*} ; \quad E=E_{w}+\left(E_{p}-E_{w}\right) . \\
&\left(\frac{\theta-\theta_{h}}{\theta_{w}-\theta_{h}}\right) \\
& \text { if } \quad \theta>\theta^{*} ; E=E_{p}
\end{aligned}
$$

where $\theta_{h}$ is the soil hygroscopic point, $\theta_{w}$ is soil moisture at expected vegetation wilting point, $\theta^{*}$ is the soil moisture reduction point, and $\mathrm{E}_{w}$ is soil evaporation at the wilting point of vegetation (Table 1). Soil evaporation was scaled by bare ground fraction $(1-f s)$ in the case of $S W E>0$ (Appendix 1).

\subsection{Transpiration and carbon assimilation}

Piñon and juniper Tr, A, and water-use efficiency [WUE: g $\mathrm{C} \mathrm{mm} \mathrm{H}_{2} \mathrm{O}$ ] were influenced by daily potential transpiration $\left[\operatorname{Tr}_{p}\right]$ and volumetric soil moisture $\left[\theta: \mathrm{mm}^{3} \mathrm{~mm}^{-3}\right]$. Values of $\operatorname{Tr}_{p}$ and relationships between $\theta, \operatorname{Tr}, W U E$ and $A$ were determined using physiological sapflow $\left[\mathrm{J}_{s}\right], \theta$, water potential $[\psi: \mathrm{kPa}]$ and gas exchange measurements in piñon and juniper tree plots. These measurements were made from 2006-2012 during a manipulative drought experiment at the SNWR (outlined in Pangle et al. (2012)), and data used in our model come from un-droughted piñon and juniper tree plots. We built a $\theta-\psi$ release curve to compare physiological measurements of gas exchange and $\mathrm{J}_{s}$ directly with $\theta$ (Equation 1), and vegetation functioning in the model is therefore scaled by both $\theta$ fluctuations and $\mathrm{E}_{p}$ at the daily time step.

For piñon and juniper, daily values of $\operatorname{Tr}_{p}$ for each species were modeled as a sine curve using sapflow data at the piñon-juniper site (Figure 2b) as:

$$
\operatorname{Tr}_{p}=\operatorname{Tr}_{0} \cdot\left[1+\delta_{T r} \cdot \sin \left(\omega_{T r} \cdot h_{d a y}+\phi_{T r}\right)\right]
$$


where $\operatorname{Tr}_{0}$ is mean annual $T r, \delta_{T r}$ is the amplitude about $T r_{0}, \omega_{T r}$ is the frequency of the sinusoid $\left[\mathrm{d}^{-1}\right], h_{d a y}$ is the hydrologic day, and $\phi_{T r}$ is the phase shift. The daily WUE of piñon and juniper trees was modeled as a linear relationship between leaf-level gas exchange and $\theta$ (Figure 2d), and piñon and juniper $W U E$ is reduced to zero at $\theta \leq 6.5 \%$ and 5\%, respectively, which corresponds to gas exchange data (Limousin et al., 2013) (Table 3). Daily Tr was calculated in a piecewise manner independently for piñon and juniper trees from Laio et al. (2001) as:

$$
\begin{aligned}
\text { if } \quad \theta \leq \theta_{w} ; \quad \operatorname{Tr}=0 \\
\text { if } \quad \theta_{w}<\theta \leq \theta^{*} ; \quad \operatorname{Tr}=\operatorname{Tr}_{p} \cdot\left(\frac{\theta-\theta_{w}}{\theta^{*}-\theta_{w}}\right) \\
\text { if } \quad \theta \geq \theta^{*} ; \quad \operatorname{Tr}=\operatorname{Tr}_{p}
\end{aligned}
$$

where $\theta_{w}$ is soil moisture at the observed vegetation wilting point for piñon (0.064) and juniper (0.051), and $\theta^{*}$ is the observed soil moisture reduction point (Table 3). In Equation $6, \theta_{w}$ and $\theta^{*}$ were calculated from field data of $\theta$ and $\mathrm{J}_{s}$ (Table 3). Daily A was calculated independently for piñon and juniper as:

$$
A=\operatorname{Tr} * W U E
$$

\subsection{Snowmelt and air temperature}

We calculated snowmelt $\left[\mathrm{S}_{m}: \mathrm{mm} \mathrm{m}^{-2} \mathrm{~d}^{-1}\right]$ from temperature $\left[\mathrm{Ta}:{ }^{\circ} \mathrm{C}\right]$ and net radiation [Rn: $\left.\mathrm{W} \mathrm{m}^{-2}\right]$ using the restricted degree-day method from Kustas et al. (1994) as:

$$
S_{m}=a r \cdot T_{d}+m q \cdot R n
$$

where $\operatorname{ar}\left(2.25 \mathrm{~mm}^{\circ} \mathrm{C}^{-1}\right.$ day $\left.^{-1}\right)$ and $m q\left(0.26 \mathrm{~mm} \mathrm{~W} \mathrm{~m}^{-2} \mathrm{~d}^{-1}\right)$ are constants from Kustas et al. (1994) and $\mathrm{T}_{d}$ is air temperature $\left({ }^{\circ} \mathrm{C}\right)$ above or below freezing $\left(0^{\circ} \mathrm{C}\right)$. We calculated daily mean air temperature as a sine curve from SNWR meteorological data at the piñon-juniper site [http://sev.lternet.edu/data/sev-1] (Figure 2a) using a similar technique to Milly (1994) as: 


$$
T_{a}=T_{a 0} \cdot\left[1+\delta_{T_{a}} \cdot \sin \left(\omega_{T_{a}} \cdot h_{d a y}+\phi_{T_{a}}\right)\right]
$$

where $T a_{p 0}$ is mean annual $T_{a}, \delta_{T_{a}}$ is the amplitude about $T_{a 0}, \omega_{T_{a}}$ is the frequency of the sinusoid $\left[\mathrm{d}^{-1}\right], h_{d a y}$ is the hydrologic day, and $\phi_{T_{a}}$ is the phase shift. Additional calculations for Rn and surface albedo $\left[\alpha_{s f c}\right]$ are in Appendix 1.

\section{Results}

Steep slopes were simulated with lower soil active depth [Zr], lower maximum infiltration $\left[\mathrm{I}_{\text {max }}\right]$ and higher slope $\left[\mathrm{S}_{l}\right]$ than moderate slopes were (Table 1). In control simulations, steep slopes had higher daily average Ta (Figure 3a), higher average net radiation [Rn: w $\left.\mathrm{m}^{-2}\right]$ (Figure 3b), lower average system moisture [ $\left.\theta+\mathrm{SWE}: \mathrm{mm}\right]$ (Figure 3c), lower evapotranspiration [ET: $\mathrm{mm} \mathrm{m}^{-2} \mathrm{~d}^{-1}$ ] (Figure 3d), and lower carbon assimilation [A: g C $\mathrm{m}^{-2} \mathrm{~d}^{-1}$ for piñon and juniper (Figure 3e).

In the climate change simulations, we increased daily average temperature $\left[\mathrm{T}_{a 0}\right]$ by $1.6^{\circ} \mathrm{C}$ on moderate slopes site and by $2.0^{\circ} \mathrm{C}$ on steep slopes, increased daily average potential evaporation $\left[E_{p 0}\right]$ by $0.5 \mathrm{~mm} \mathrm{day}^{-1}$ on moderate slopes and by $0.6 \mathrm{~mm} \mathrm{~d}^{-1}$ on steep slopes, slightly decreased average precipitation event magnitude $[\alpha]$ in December-March, and decreased the probability of snowfall accumulation in December-March (Table 2). The climate change scenario slightly decreased total precipitation, but did not produce large reductions of average $\theta$ or $\mathrm{E}$ (Table 4). Instead, these simulations increased differences between the moderate and steep slope site environments; SWE and snow cover fraction $(f s)$ were reduced to a greater degree on steep slopes compared to moderate slopes, and surface albedo $\left[\alpha_{s f c}\right]$ was reduced to a greater percentage on moderate slopes (Table 4). The steep slope site experienced increasing daily variance in $\theta+\operatorname{SWE}\left[\sigma_{\theta+S W E}\right]$ and $\mathrm{E}$ $\left[\sigma_{E}\right]$, while the moderate slope site showed a decrease in $\sigma_{\theta+S W E}$ and a lesser increase in $\sigma_{E}$ (Table 4). On steep slopes, daily E, $\operatorname{Tr}, \frac{T r}{E}$ and A decreased in the climate change 

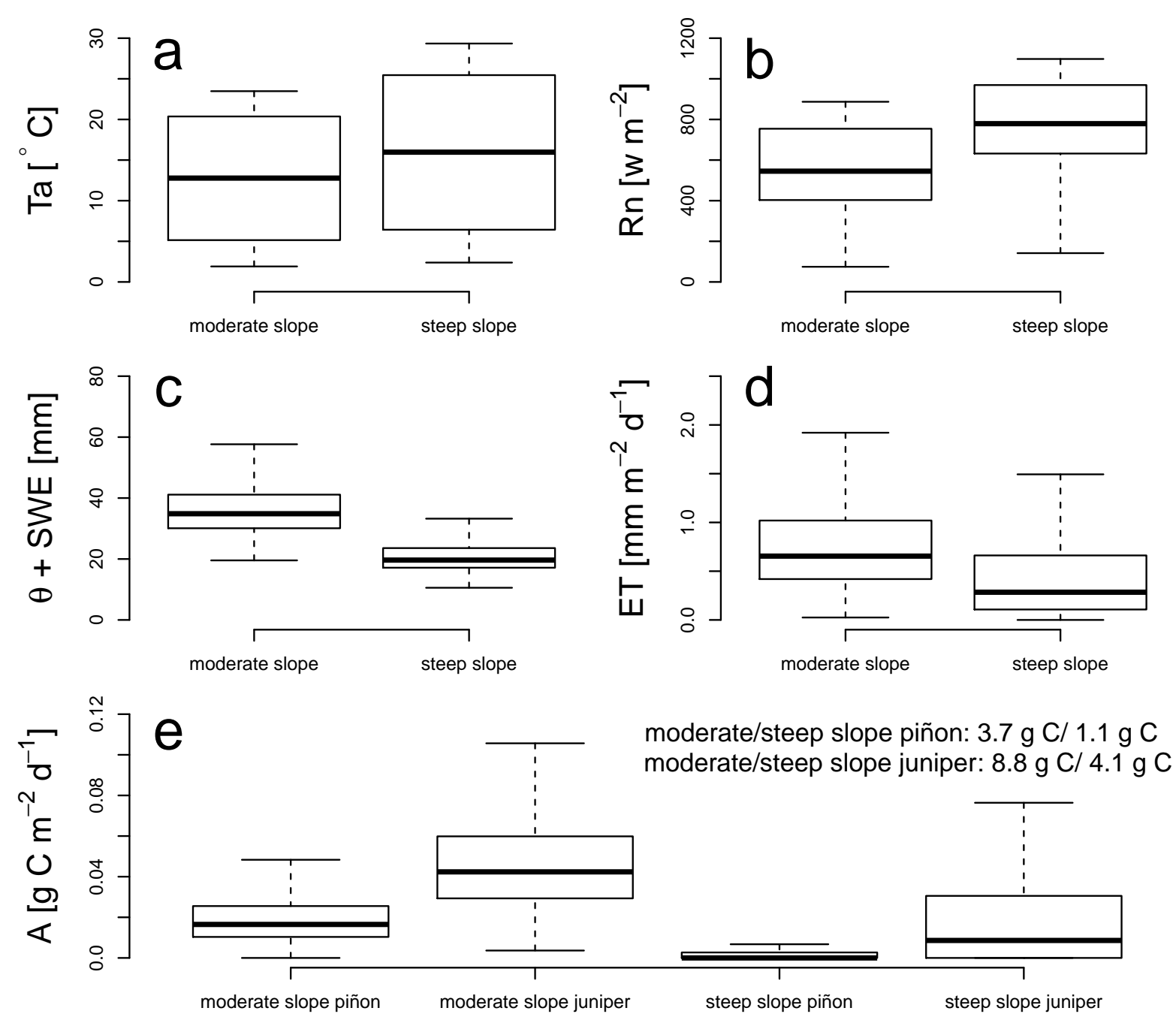

Figure 3: Comparison of December-May air temperature [Ta: $\left.{ }^{\circ} \mathrm{C}\right]($ Panel a), net radiation $\left[\right.$ Rn: $\mathrm{w} \mathrm{m}^{-2}$ day $\left.^{-1}\right]$ (Panel b), total system moisture (soil moisture + snow water equivalent) $[\theta+$ SWE: $\mathrm{mm}]$ (Panel c), evapotranspiration [ET: $\left.\mathrm{mm} \mathrm{day}^{-1}\right]$ (Panel d), and piñon and juniper carbon assimilation [A: $\mathrm{g} \mathrm{C} \mathrm{m}^{-2}$ day $^{-1}$ ] (Panel e) for the moderate slope control and steep slope control simulations. Average December-May A is shown in Panel e. 
Table 4: Percent change in moderate slope and steep slope variables for the climate change scenario, December - May averages.

\begin{tabular}{|c|l|cc|}
\hline Variable & Name & Moderate slope \% & Steep slope $\%$ \\
\hline $\mathrm{P}$ & total precipitation & -0.1 & -0.1 \\
$\theta$ & soil moisture & 0 & 0 \\
$\mathrm{SWE}$ & snow water equivalent & -31.8 & -100 \\
$\theta+\mathrm{SWE}$ & & -0.6 & -0.7 \\
$\sigma_{\theta+S W E}$ & $\theta+$ SWE variance & -0.9 & +1.7 \\
\hline $\mathrm{fS}$ & snow cover fraction & -33.1 & -100 \\
$\alpha_{s f c}$ & surface albedo & -4.5 & -1.0 \\
$\mathrm{Rn}$ & net radiation & +1.0 & +0.2 \\
\hline $\mathrm{E}$ & evaporation & 0 & -0.3 \\
$\sigma_{E}$ & E variance & +0.7 & +2.6 \\
$\operatorname{Tr}_{p}$ & piñon transpiration & -0.3 & -3.5 \\
$\operatorname{Tr}_{j}$ & juniper transpiration & -0.1 & -2.1 \\
$\frac{T r}{E}$ & & 0 & -1.9 \\
\hline $\mathrm{A}_{p}$ & piñon assimilation & -0.4 & -3.7 \\
$\mathrm{~A}_{j}$ & juniper assimilation & -0.3 & \\
\hline
\end{tabular}

simulation, whereas these variables showed small to no decreases on moderate slopes (Table 4). As the ratio of control to climate change simulations, climate change increased $\sigma_{\theta+S W E}$ and $\sigma_{\epsilon}\left(\epsilon=\frac{E}{E_{p}}\right)$ to a greater degree on steep compared to moderate slopes (Figure 4), yet normalized reductions in $\theta+$ SWE were small due to high water limitation at both sites (Figure 4a). This suggests that lower $\epsilon$ was produced by increased daily $\mathrm{E}_{p}$ and not by decreased daily E.

As a result of climate change, the spring growing season (March-May) experienced small reductions in $\theta+\mathrm{SWE}$ and in $\mathrm{ET}(\mathrm{E}+\mathrm{Tr})$ on both moderate and steep slopes, piñon and 
juniper on steep slopes experienced higher reductions in A than they did on the moderate slope, and piñon pines experienced higher reductions in A than junipers did (Figure 5). Piñon pines had higher potential $\operatorname{Tr}\left[\operatorname{Tr}_{0}\right]$ than junipers, yet also had higher wilting point $\theta$ $\left[\theta_{w}\right]$ and higher reduction point $\theta$ for $\operatorname{Tr}\left[\theta^{*}\right]$ (Table 3 ). Climate change also altered the timing of the spring growing season; maximum spring Tr occurred 6 days earlier at the moderate slope site (March 25 vs. March 31), and 10 days earlier at the steep slope site (March 19 vs. March 29). The magnitude of maximum Tr was reduced on the moderate slope and was increased on the steeper slope $(-2.4 \%$ moderate, $+1.3 \%$ steep $)$. The timing of spring A also changed; both moderate and steep slope sites had proportionally higher A in March in the majority of simulated years, and proportionally lower A in April-May (Figures 6 and 7). The steep slope site had greater proportional variance in A than that of the moderate slope site, and also a higher frequency of days of zero A by piñon and juniper - illustrated by no change in A ratio at very low ranking days - which did not occur on moderate slopes (Figures 6,7).

\section{Discussion}

We simulated the ecology and near-surface hydrology of piñon pine-juniper woodlands from December-May under 4 different scenarios: 1) Control moderate slopes; 2) Control steep slopes; 3) Climate change (+50 y) moderate slopes; and 4) Climate change (+50 y) steep slopes. The climate change scenario increased average daily temperature $\left(+1.6{ }^{\circ} \mathrm{C}\right.$ moderate slopes, $+2.0{ }^{\circ} \mathrm{C}$ steep slopes $)$ and slightly reduced winter precipitation $(-0.11 \mathrm{~mm}$ month $^{-1}$ ). Climate change reduced average winter snowcover (Table 4), decreased surface albedo (Table 4), and altered daily variance in system moisture $(\theta+\mathrm{SWE})$ and evaporation (Figure 4). As a result, moderate slope piñon and juniper trees experienced slight reductions in average $\operatorname{Tr}$ and A, and steep slope piñon and juniper trees experienced small but relatively larger reductions in Tr and A (Table 4). During spring (March-May), climate change reduced $\theta+\mathrm{SWE}$ and $\mathrm{ET}(\mathrm{E}+\mathrm{Tr})$, and reduced $\mathrm{A}$ on both moderate and 

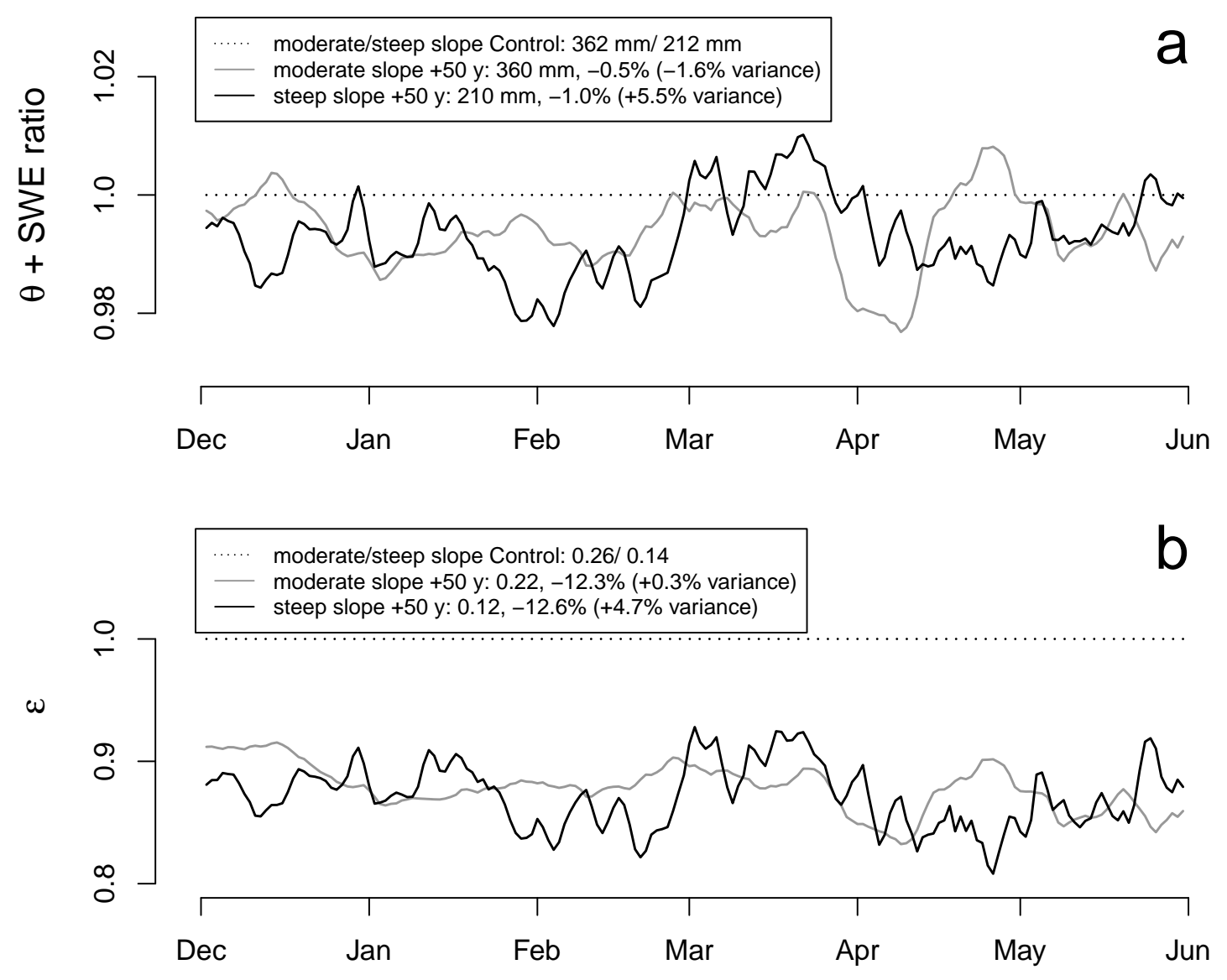

Figure 4: Ratio of climate change ( $+50 \mathrm{y})$ to control simulations in moderate slope and steep slope sites for $\theta+\operatorname{SWE}$ (Panel a) and $\epsilon\left[\frac{E}{E p}\right]$ (Panel b). Lines correspond to the floating 3-day mean. Moderate slope climate change simulations had $0.5 \%$ lower $\theta+$ SWE and $1.6 \%$ lower variance in $\theta+$ SWE than in moderate slope control simulations, as well as $12.3 \%$ lower $\epsilon$ and $0.3 \%$ higher variance in $\epsilon$. Steep slope climate change simulations had $1.0 \%$ lower $\theta+$ SWE and $5.5 \%$ higher variance in $\theta+$ SWE compared to steep slope control simulations, as well as $12.6 \%$ lower $\epsilon$ and $4.7 \%$ higher variance in $\epsilon$. 

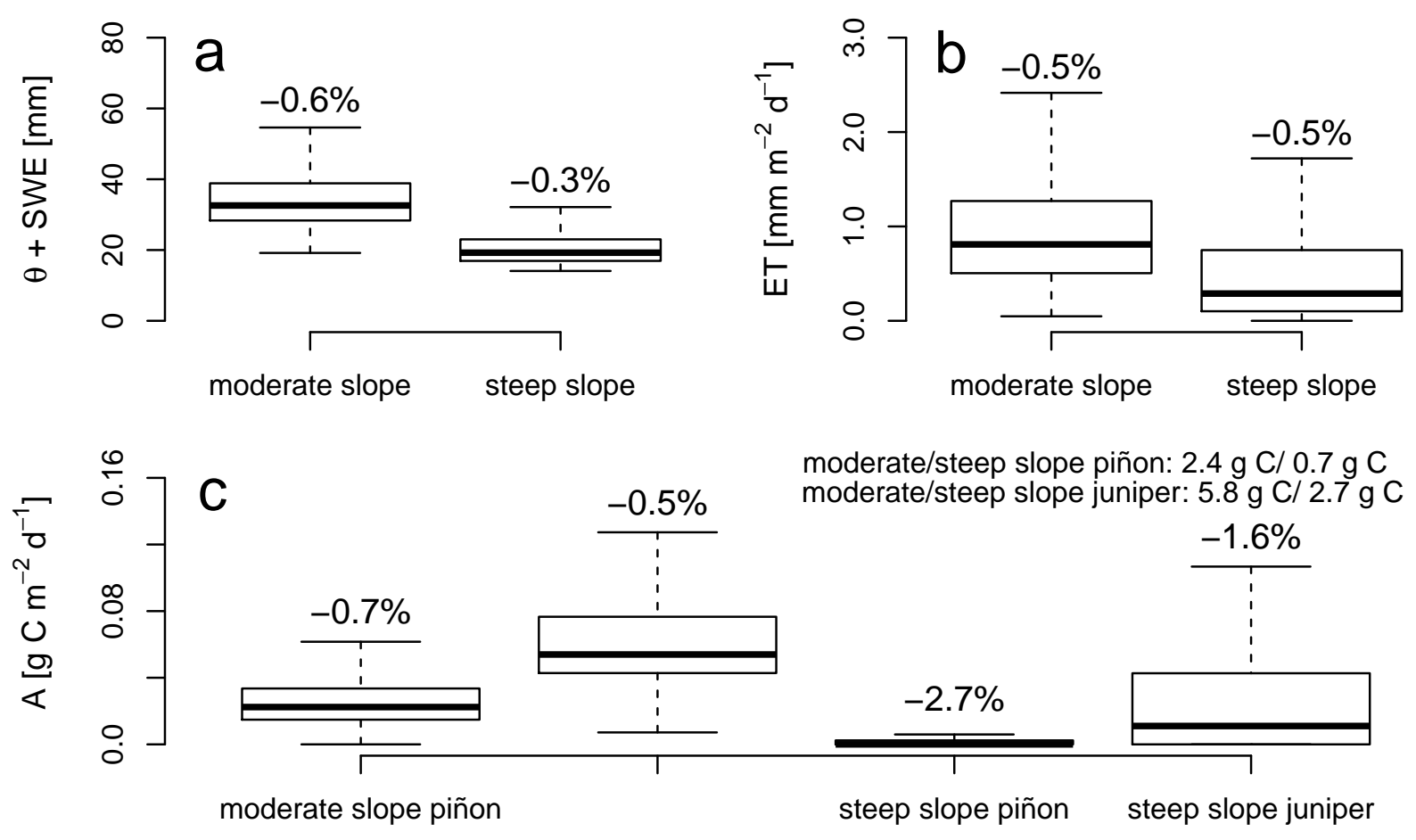

Figure 5: Comparison of March-May total system moisture (soil moisture + snow water equivalent) $[\theta+$ SWE: $\mathrm{mm}]$ (Panel a), evapotranspiration [ET: $m$ day $\left.^{-1}\right]($ Panel b), and piñon and juniper carbon assimilation $\left[\mathrm{A}: \mathrm{g} \mathrm{C} \mathrm{m}^{-2}\right.$ day $\left.^{-1}\right]$ (Panel c) for the moderate slope climate change and steep slope climate change $(+50$ y) simulations. Percent change in variables for the climate change simulations is in relation to March-May values for the moderate slope control and steep slope control simulations. Average March-May A is shown in Panel c.

steep slopes (Figure 5). Climate change also shifted the timing of A towards earlier March dates, and April and May experienced lower A in the majority of days (Figures 6 and 7). These results support our postulated hypothesis that, by inducing greater variance in moisture availability and moisture fluxes, winter climate change promotes earlier peaks of spring A in piñon-juniper woodlands and results in small reductions in A at steep slope sites, with greater negative impacts on piñon compared to juniper trees.

Regardless of the influence of winter climate change, seasonal precipitation patterns and 
the occurrence of global-change-type drought events are likely to remain the primary influence of piñon-juniper functioning in the future. Regional drought events have had a large influence on tree mortality and ecosystem structure in piñon-juniper woodlands over the past 100 years (Breshears et al., 2005; Allen et al., 2010), and seasonal rainfall is the primary driver of productivity in these woodlands in a single year (Weiss et al., 2004b,a; Limousin et al., 2013). Across western US forests and woodlands, the importance of winter and spring climate change is likely to hinge on the effect that changing winter and spring conditions have on the severity of disturbance events including drought, fire and insect outbreaks (Parker et al., 2006; Hicke and Jenkins, 2008). Climate projections for the southwestern US call for greater summer aridity that is produced by increasing temperatures and slight reductions in rainfall (Seager et al., 2007; Seager and Vecchi, 2010; Gutzler and Robbins, 2011; Notaro et al., 2012), and a slightly later onset of the summer monsoon season, which normally occurs July-September (Seager and Vecchi, 2010; Seth et al., 2011). The timing and magnitude of summer precipitation in the southwestern US is also predicted to shift towards a greater frequency of smaller rainfall events (Weltzin et al., 2003), which may reduce average soil moisture availability and biotic processes in semiarid systems even if total precipitation remains unchanged (Heisler-White et al., 2008; Johnson et al., 2012; Vargas et al., 2012). Should these changes result in a more arid early summer (June-July), our results show that piñon-juniper woodlands will, on average, begin this season at a lower carbon status, potentially exacerbating the effects of dry summer conditions.

Piñon and juniper trees on steep slopes were more sensitive to climate change due to their lower active soil depth, which intensified fluctuations in $\theta, \mathrm{E}$ and $\mathrm{A}$. Piñon and juniper trees are adept at drawing moisture from lower soil layers and from groundwater sources, which may minimize the effects of moisture limitation in many cases (Flanagan et al., 1992; Williams and Ehleringer, 2000), yet the active soil depths at our study sites are comparatively shallow to those of other woodlands and do not have accessible groundwater 


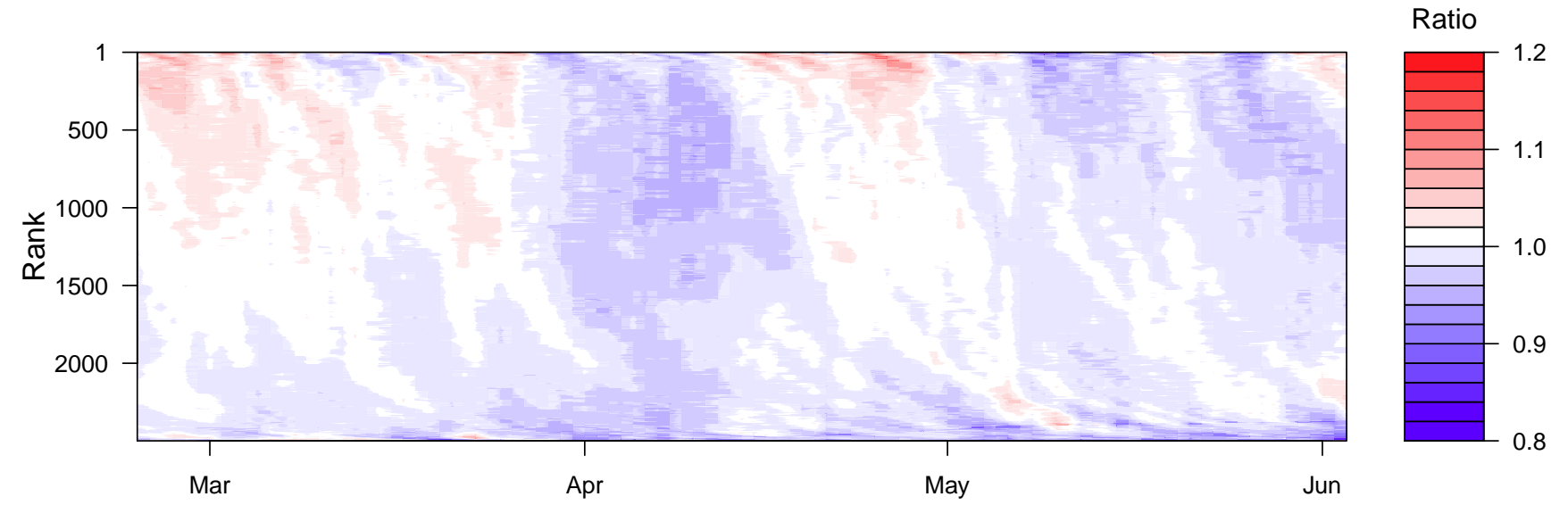

Figure 6: Ranked daily carbon assimilation ratio $\left[\mathrm{A}: \mathrm{g} \mathrm{C} \mathrm{m}^{-2}\right.$ day $\left.^{-1}\right]$ from March-May for moderate slope sites. Ranked (largest to smallest) A values for climate change $(+50 \mathrm{y})$ simulations were divided by ranked A values for control simulations to determine the A ratio (2500 values for each day correspond to 2500 simulations).

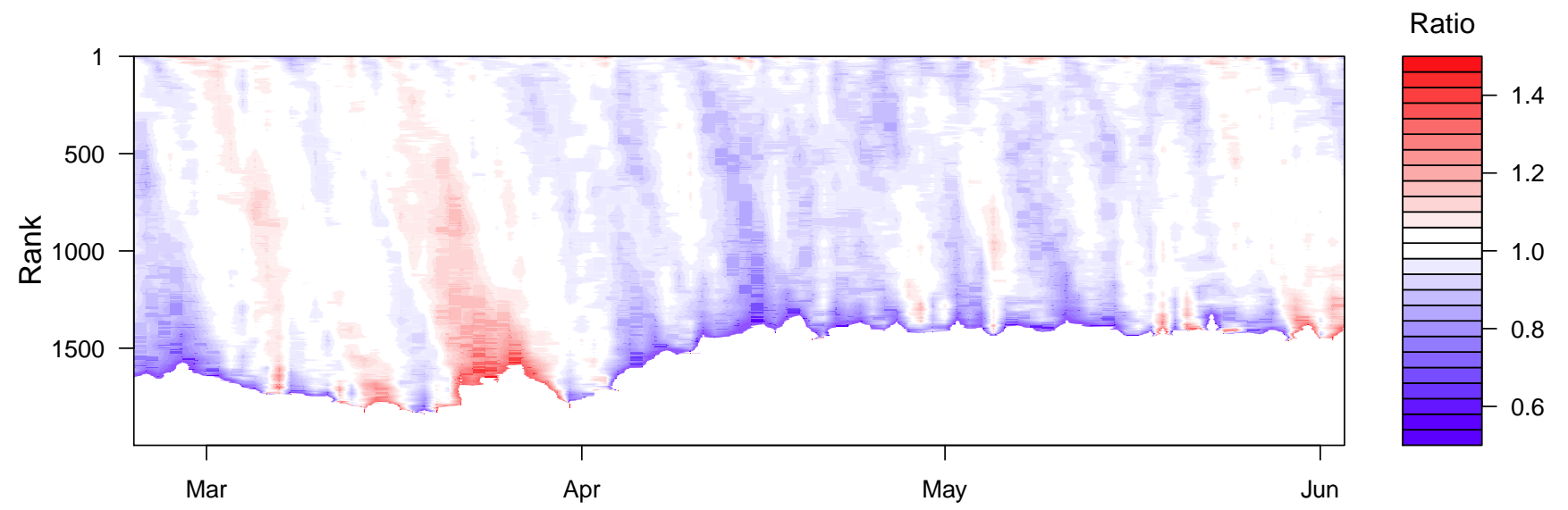

Figure 7: Ranked daily carbon assimilation ratio [A: $\mathrm{g} \mathrm{C} \mathrm{m}^{-2}$ day $\left.{ }^{-1}\right]$ from March-May for steep slope sites. Ranked (largest to smallest) A values for climate change (+50 y) simulations were divided by ranked A values for control simulations to determine the A ratio (2500 values for each day correspond to 2500 simulations). A ratio was not available when either simulation resulted in a daily A value of zero. 
(400 $\mathrm{mm}$ depth on steep slopes, $800 \mathrm{~mm}$ on moderate slopes). In our study, climate change reduced A on moderate slopes in $46.3 \%$ of days from December-May and in $60.6 \%$ of days from March-May, and reduced A on steep slopes in $42.0 \%$ of days from December-May and in $74.3 \%$ of days from March-May (Figure 4). These reductions correspond to different patterns of moisture availability and evaporation between moderate and steep slopes (Figures 3, 4, 5). Although climate change reduced total A (Table 4, Figure 5), the percentage of cumulative December-May A that occurred in spring was only slightly reduced on moderate slopes $(66.5 \%,-0.2 \%)$, and was slightly increased on steep slopes $(67.1 \%,+0.6 \%)$. Thus, the relatively larger reductions in total A that occurred on steep slopes (Table 4, Figure 7) correspond to higher within-season variance in $\theta, \mathrm{E}$ and $\operatorname{Tr}$ (Figure 4, Table 4) that was produced by lower soil active depth and corresponding moisture storage on steep slopes. The seasonal shift in spring towards higher Tr and A in March was ultimately offset by lower $\operatorname{Tr}$ and A in April and May, resulting in a net reduction in these exchanges on steep slopes (Table 4, Figure 7). Winter climate change is not likely to decrease precipitation or soil moisture availability to a large degree (Table 4), yet our results show that the altered timing of $\theta$ and $\mathrm{E}$ and increasing daily variance in $\mathrm{E}$ and $\theta+$ SWE will likely reduce $\frac{T r}{E}$ on steep slopes and slightly reduce A in late spring. Due to the shallow soils that occur at our simulation sites, which do not buffer piñon and juniper trees from moisture limitation as well as deeper soils do, it is likely that the responses we observed to climate change at our sites are stronger than those that would occur at lowland sites with deeper soil.

Historical drought events have had greater negative impacts on piñon pines compared to junipers, and junipers incur a lower incidence of mortality due to moisture limitation (Plaut et al., 2012, 2013; Limousin et al., 2013). Our results corroborate studies that suggest drier future conditions will have greater negative impacts on piñon pines (Plaut et al., 2012; Limousin et al., 2013; Gaylord et al., 2013). Piñon pines had higher potential Tr compared to junipers, yet also experienced larger reductions in Tr, A and WUE as soil 
moisture was depleted (Tables 3 and 4). Thus, our model simulations show that piñon pines were better suited than junipers to maximize periods of high moisture availability at the cost of much lower functioning during periods of moisture deficit, which is consistent with other studies comparing these species (McDowell et al., 2008; Plaut et al., 2012; Limousin et al., 2013). On steep slopes, juniper A was reduced to a greater magnitude than it was for piñon pines (-0.04 $\mathrm{g} \mathrm{C} \mathrm{m}^{-2}$ piñon, -0.09 $\mathrm{g} \mathrm{C} \mathrm{m}^{-2}$ juniper), but piñon pines still had a greater proportional reduction in A (Table 4, Figure 5). When scaled to the tree level, the average piñon pine on steep slopes experienced a reduction in $\mathrm{A}$ of $5.1 \mathrm{~g} \mathrm{C}$ from December-May, while the average juniper experienced a reduction of $1.7 \mathrm{~g} \mathrm{C}$. This reduction in $\mathrm{A}$ is likely of greater consequence for piñon pines due to their isohydric regulation of leaf water potential. By closing their stomata during periods of water limitation, piñon pines reduce the likelihood of hydraulic failure, but increase the risk of carbon starvation (Plaut et al., 2012; Limousin et al., 2013). We hypothesize that the risk of carbon starvation in piñon pines during summer drought events in the 21st century will be compounded by lower spring A prior to these events. Our study did not account for species acclimation to multi-year water limitation (Limousin et al., 2013), stand densities and understory vegetation (Romme et al., 2009; Royer et al., 2012), and facilitation of deeper moisture percolation via soil water repellency (Lebron et al., 2007; Robinson et al., 2010), all of which may potentially lessen the effects of moisture limitation in these woodlands. Yet it remains unclear to what degree tree and stand-level acclimations can insulate these woodlands from the effects of unfavorable changes in climate. Future climate change in the southwestern US is likely to produce conditions similar to those that produced widespread tree mortality in these ecosystems in the 20th century (Breshears et al., 2005, 2009; Allen et al., 2010), and small changes in winter and spring climate may increase the susceptibility of these ecosystems, and especially isohydric piñon species, to summer drought events in the 21st century. 


\section{Acknowledgments}

This research was partially funded by a National Science Foundation grant to the University of New Mexico for Long Term Ecological Research at the Sevilleta LTER. The rainfall manipulation experiment was supported by the US DOE Office of Science (BER).

\section{Appendix}

\subsection{Net radiation}

We modeled daily net radiation $\left[\mathrm{Rn}: \mathrm{W} \mathrm{m}^{2}\right.$ day $\left.^{-1}\right]$ from Dubayah (1994) as:

$$
R n=S_{t}+\left(\epsilon \cdot \sigma \cdot T_{a}^{4}\right)-\left(\epsilon \cdot \sigma \cdot T_{a}^{4}\right)
$$

Where $\mathrm{S}_{t}$ is net incoming shortwave radiation $\left(\mathrm{w} \mathrm{m}^{2}\right.$ day $\left.^{-1}\right), \epsilon$ is the atmospheric emissivity, and $\sigma$ is the Stefan-Boltzmann constant. We calculated $\mathrm{S}_{t}$ as the sum of net direct $\left(\mathrm{S}_{b}\right)$ and net diffuse $\left(\mathrm{S}_{d}\right)$ shortwave radiation. We calculated net direct shortwave radiation as:

$$
S_{b}=S_{p} \cdot \cos \left(\psi_{S_{l}}\right) \cdot\left(1-\alpha_{s f c}\right)
$$

Where $\psi_{S_{l}}$ is the effective solar zenith angle (including site slope, $\mathrm{S}_{l}$ ) and $\alpha_{s f c}$ is average daily surface albedo. We calculated total incident shortwave radiation $\left(\mathrm{S}_{p}\right)$ as:

$$
S_{p}=S_{p 0} \cdot \tau^{m}
$$

Where $\tau$ is mean atmospheric transmittance (\%), $\mathrm{S}_{p 0}$ is the solar constant $\left(1380 \mathrm{~W} \mathrm{~m}^{2}\right.$ $\mathrm{s}^{-1}$ ), and $m$ is optical air mass (units), calculated as:

$$
m=\frac{p p o}{\cos \psi+0.50572 \cdot\left(96.07995-\psi^{-1.6364}\right)}
$$

Where ppo is atmospheric density calculated as:

$$
\text { ppo }=e^{-\frac{E_{v}}{8434.5}}
$$


Where $\mathrm{E}_{v}$ is site elevation (meters). We calculated incoming diffuse shortwave radiation $\left(\mathrm{S}_{d i}\right)$ as:

$$
S_{d i}=\left(0.3 \cdot\left(1-\tau^{m}\right) \cdot S_{p 0} \cdot \cos \psi_{S_{l}}\right) \cdot V_{d}
$$

Where $\mathrm{V}_{d}$ is the sky view fraction (\%). We calculated outgoing diffuse shortwave radiation $\left(\mathrm{S}_{d o}\right)$ as:

$$
S_{d o}=C_{t} \cdot S_{d i} \cdot \alpha_{s f c}
$$

Where $\mathrm{C}_{t}$ is a configuration factor of terrain irradiance, calculated as:

$$
C_{t}=\frac{1+\cos S_{l}}{2}-V_{d}
$$

Where $\mathrm{S}_{l}$ is the site slope $(\%)$.

\subsection{Solar zenith angle and day length}

Daily mean solar zenith angle was calculated from Campbell and Norman (2008) as:

$$
\cos \psi=\sin L a t \cdot \sin \delta+\cos L a t \cdot \cos \delta \cdot \cos \left(15 \cdot\left(t-t_{0}\right)\right)
$$

Where $\delta$ is the solar declination angle, Lat is site latitude and $t$ is time [hr] since $t_{0}$. We did not account for azimuth angle in this model and all simulations are therefore on south-facing slopes.

\subsection{Snow and surface albedo}

We estimated snow cover fraction $[f s]$ in a piecewise manner from snow water equivalent $[S W E ; \mathrm{mm}]$ as:

$$
\begin{aligned}
\text { if } S W E \geq 0.5 \cdot S W E_{\max } ; & f s=1.0 \\
\text { if } S W E>0 \text { \& } S W E<0.5 \cdot S W E_{\max } ; & f s=\left(\frac{S W E}{0.5 \cdot S W E_{\max }}\right) \\
& \text { if } S W E=0 ; \quad f s=0
\end{aligned}
$$


where $S W E_{\max }$ is maximum snow water equivalent [300 $\mathrm{mm}$; Table 1]. We calculated surface albedo from $f s$ using constant surface albedo $\left[\alpha_{s f c} ;\right.$ Table 1]. Snow albedo $\left[\alpha_{\text {snow }}\right]$ was calculated from Campbell and Norman (2008) as:

$$
\alpha_{\text {snow }}=\alpha_{\text {snowmax }} \cdot 0.94^{0.58^{T}}
$$

where $\alpha_{\text {snowmax }}$ is maximum snow albedo (Table 1 ) and $T$ is the number of days since snowfall.

\section{References}

Allen, C., Macalady, A., Chenchouni, H., Bachelet, D., McDowell, N., Vennetier, M., Kitzberger, T., Rigling, A., Breshears, D., Hogg, E., Gonzalez, P., Fensham, R., Zhang, Z., Castro, J., Demidova, N., Lim, J., Allard, G., Running, S., Semerci, A., Cobb, N., 2010. A global overview of drought and heat-induced tree mortality reveals emerging climate change risks for forests. Forest Ecology and Management 259, 660-684, doi:10.1016/j.foreco.2009.09.001.

Baldocchi, D. D., Xu, L., 2007. What limits evaporation from Mediterranean oak woodlands - The supply of moisture in the soil, physiological control by plants or the demand by the atmosphere? Advances in Water Resources 30, 2113-2122, doi:10.1016/j.advwatres.2006.06.013.

Baron, J., Hartman, M., Band, L., Lammers, R., 2000. Sensitivity of a high-elevation Rocky Mountain watershed to altered climate and CO2. Water Resources Research 36, 89-99, doi:10.1029/1999WR900263.

Brandes, D., Wilcox, B., 2000. Evapotranspiration and soil moisture dynamics on a semiarid ponderosa pine hillslope. Journal of the American Water Resources Association 36, 965974, doi:10.1111/j.1752-1688.2000.tb05702.x.

Breshears, D. D., Cobb, N. S., Rich, P. M., Price, K. P., Allen, C. D., Balice, R. G., Romme, W. H., Kastens, J. H., Floyd, M. L., Belnap, J., Anderson, J. J., Myers, O. B., Meyer, 
C. W., 2005. Regional vegetation die-off in response to global-change-type drought. PNAS 102, 15144-15148, doi:10.1073/pnas.0505734102.

Breshears, D. D., Myers, O. B., Meyer, C. W., Barnes, F. J., Zou, C. B., Allen, C. D., McDowell, N. G., Pockman, W. T., 2009. Tree die-off in response to global change-type drought: mortality insights from a decade of plant water potential measurements. Frontiers in Ecology and the Environment 7, 185-189, doi:10.1890/080016.

Brunsell, N. A., Wilson, C. J., 2013. Multiscale Interactions between Water and Carbon Fluxes and Environmental Variables in A Central U.S. Grassland. Entropy 15 (4), 13241341, doi:10.3390/e15041324.

Campbell, G., Norman, J., 2008. An introduction to environmental biophysics, 2nd Edition. Springer, New York.

Cavanaugh, M., Kurc, S., Scott, R., 2011. Evapotranspiration partitioning in semiarid shrubland ecosystems: a two-site evaluation of soil moisture control on transpiration. Ecohydrology 4, 671-681, doi:10.1002/eco.157.

Daly, E., Porporato, A., 2005. A review of soil moisture dynamics: From rainfall infiltration to ecosystem response. Environmental Engineering Science 22 (1), 9-24.

Daly, E., Porporato, A., 2006. Impact of hydroclimatic fluctuations on the soil water balance. Water Resources Research 42, 1-11.

Diffenbaugh, N. S., Giorgi, F., Pal, J. S., 2008. Climate change hotspots in the United States. Geophysical Research Letters 35, doi:doi:10.1007/s00704-011-0484-y.

D’Odorico, P., Ridolfi, L., Porporato, A., Rodriguez-Iturbe, I., 2000. Preferential states of seasonal soil moisture: The impact of climate fluctuations. Water Resources Research 36 (8), 2209-2219.

Dubayah, R., 1994. Modeling a solar-radiation topoclimatology for the Rio-Grande river basin. Journal of Vegetation Science 5, 627-640, doi:10.2307/3235879. 
Flanagan, L., Ehleringer, J., Marshall, J., 1992. Differential uptake of summer precipitation among cooccurring trees and shrubs in a pinyon-juniper woodland. Plant Cell and Environment 15, 831-836, doi:10.1111/j.1365-3040.1992.tb02150.x.

Forzieri, G., Castelli, F., Vivoni, E., 2011. Vegetation dynamics within the North American Monsoon region. Journal of Climate 24, 1763-1783, doi:10.1175/2010JCLI3847.1.

Gaylord, M. L., Kolb, T. E., Pockman, W. T., Plaut, J. A., Yepez, E. A., Macalady, A. K., Pangle, R. E., McDowell, N. G., 2013. Drought predisposes pinon-juniper woodlands to insect attacks and mortality. New Phytologist 198, 567-578, doi:10.1111/nph.12174.

Granier, A., 1987. Evaluation of transpiration in a douglas-fir stand by means of sap flow measurements. Tree Physiology 3, 309-319.

Gutzler, D., Robbins, T., 2011. Climate variability and projected change in the western United States: regional downscaling and drought statistics. Climate Dynamics 37, 835849, doi:10.1007/s00,382-010-0838-7.

Heisler-White, J. L., Knapp, A. K., Kelly, E. F., 2008. Increasing precipitation event size increases aboveground net primary productivity in a semi-arid grassland. Oecologia, 129140, doi:10.1007/s00442-008-1116-9.

Hicke, J., Jenkins, J., 2008. Mapping lodgepole pine stand structure susceptibility to mountain pine beetle attack across the western United States. Forest Ecology and Management 255, 1536-1547, doi:10.1016/j.foreco.2007.11.027.

Huxman, T., Snyder, K., Tissue, D., Leffler, A., Ogle, K., Pockman, W., Sandquist, D., Potts, D., Schwinning, S., 2004. Precipitation pulses and carbon fluxes in semiarid and arid ecosystems. Oecologia 141, 254-268, doi:10.1007/s00442-004-1682-4.

Johnson, S., Kuske, C., Carney, T., Housman, D., Gallegos-Graves, L., Belnap, J., 2012. Increased temperature and altered summer precipitation have differential effects on bi- 
ological soil crusts in a dryland ecosystem. Global Change Biology 18, 2583-2593, doi:10.1111/j.1365-2486.2012.02709.x.

Katul, G., Porporato, A., Oren, R., 2007. Stochastic dynamics of plant-water interactions. The Annual Review of Ecology, Evolution, and Systematics 37, 767-791, doi:10.1146/annurev.ecolsys.38.091206.095748.

Kleinman, S. J., DeGomez, T. E., Snider, G. B., Williams, K. E., 2012. Large-Scale Pinyon Ips (Ips confusus) Outbreak in Southwestern United States Tied with Elevation and Land Cover. Journal of Forestry 110, 194-200, doi:10.5849/jof.11-060.

Kurc, S. A., Small, E. E., 2007. Soil moisture variations and ecosystem-scale fluxes of water and carbon in semiarid grassland and shrubland. Water Resources Research 43, doi:10.1029/2006WR005011.

Kustas, W., Rango, A., Uijlenhoet, R., 1994. A simple energy budget algorithm for the snowmelt runoff model. Water Resources Research 30, 1515-1527, doi:10.1029/94WR00152.

Ladwig, L., Ratajczak, Z., Ocheltree, T., Hafich, K., Churchill, A., Frey, S., Fuss, C., Kazanski, C., Muñoz, J., Petrie, M., Reinmann, A., Smith, J., 2015. Beyond arctic and alpine: The influence of winter climate on temperate ecosystems. Ecology, in press.

Laio, F., Porporato, A., Ridolfi, L., Rodriguez-Iturbe, I., 2001. Plants in water-controlled ecosystems: active role in hydrologic processes and response to water stress - II. Probabilistic soil moisture dynamics. Advances in Water Resources 24 (7), 707-723.

Lebron, I., Madsen, M., Chandler, D., Robinson, D., Wendroth, O., Belnap, J., 2007. Ecohydrological controls on soil moisture and hydraulic conductivity within a pinyon-juniper woodland. Water Resources Research 43, 1-15, doi:10.1029/2006WR005398.

Limousin, J.-M., Bickford, C. P., Dickman, L. T., Pangle, R. E., Hudson, P. J., Boutz, A. L., Gehres, N., Osuna, J. L., Pockman, W. T., McDowell, N. G., 2013. Regulation and 
acclimation of leaf gas exchange in a pinon-juniper woodland exposed to three different precipitation regimes. Plant, Cell and Environment 36, 1812-1825, doi:10.1111/pce.12089.

Makela, A., Berninger, F., Hari, P., 1996. Optimal control of gas exchange during drought: Theoretical analysis. Annals of Botany 77 (5), 461-467.

McDowell, N. G., White, S., Pockman, W. T., 2008. Transpiration and stomatal conductance across a steep climate gradient in the southern Rocky Mountains. Ecohydrology 1, 193204, doi:10.1002/eco.20.

Mendez-Barroso, L. A., Vivoni, E. R., 2010. Observed shifts in land surface conditions during the North American Monsoon: Implications for a vegetation-rainfall feedback mechanism. Journal of Arid Environments 74, 549-555, doi:10.1016/j.jaridenv.2009.09.026.

Milly, P., 1994. Climate, soil water storage, and average annual water balance. Water Resources Research 30, 2143-2156.

Monson, R., Sparks, J., Rosentiel, T., Scott-Denton, L., Huxman, T., Harley, P., Turnipseed, A., Burns, S., Backlund, B., Hu, J., 2005. Climatic influences on net ecosystem CO2 exchange during the transitions from wintertime carbon source to springtime carbon sink in a high-elevation, subalpine forest. Oecologia 146, 130-147.

Notaro, M., Mauss, A., Williams, J. W., 2012. Projected vegetation changes for the American Southwest: combined dynamic modeling and bioclimatic-envelope approach. Ecological Applications 22, 1365-1388.

Pangle, R. E., Hill, J. P., Plaut, J. A., Yepez, E. A., Elliot, J. R., Gehres, N., McDowell, N. G., Pockman, W. T., 2012. Methodology and performance of a rainfall manipulation experiment in a pinon-juniper woodland. Ecosphere 3, doi:10.1890/ES11-00369.1.

Parker, T., Clancy, K., Mathiasen, R., 2006. Interactions among fire, insects and pathogens in coniferous forests of the interior western United States and Canada. Agricultural and Forest Entomology 8, 167-189, doi:10.1111/j.1461-9563.2006.00305.x. 
Petrie, M. D., Brunsell, N. A., 2012. The role of precipitation variability on the ecohydrology of grasslands. Ecohydrology 5, 337-345, doi:10.1002/eco.224.

Petrie, M. D., Brunsell, N. A., Nippert, J. B., 2012. Climate change alters growing season flux dynamics in mesic grasslands. Theoretical and Applied Climatology 107, 427-440, doi:10.1007/s00704-011-0484-y.

Plaut, J. A., Wadsworth, W. D., Pangle, R., Yepez, E. A., McDowell, N. G., Pockman, W. T., 2013. Reduced transpiration response to precipitation pulses precedes mortality in a pinon-juniper woodland subject to prolonged drought. New Phytologist 200, 375-387, doi:10.1111/nph.12392.

Plaut, J. A., Yepez, E. A., Hill, J., Pangle, R., Sperry, J. S., Pockman, W. T., Mcdowell, N. G., 2012. Hydraulic limits preceding mortality in a pinon-juniper woodland under experimental drought. Plant, Cell and Environment 35, 1601-1617, doi:10.1111/j.13653040.2012.02512.x.

Porporato, A., Daly, E., Rodriguez-Iturbe, I., 2004. Soil water balance and ecosystem response to climate change. American Naturalist 164, 625-632.

Porporato, A., Laio, F., Ridolfi, L., Caylor, K. K., Rodriguez-Iturbe, I., 2003. Soil moisture and plant stress dynamics along the Kalahari precipitation gradient. Journal of Geophysical Research-Atmospheres 108.

Porporato, A., Laio, F., Ridolfi, L., Rodriguez-Iturbe, I., 2001. Plants in water-controlled ecosystems: active role in hydrologic processes and response to water stress - III. Vegetation water stress. Advances in Water Resources 24, 725-744.

Poulter, B., Frank, D., Ciais, P., Myneni, R. B., Andela, N., Bi, J., Broquet, G., Canadell, J. G., Chevallier, F., Liu, Y. Y., Running, S. W., Sitch, S., van der Werf, G. R., 2014. Contribution of semi-arid ecosystems to interannual variability of the global carbon cycle. Nature 509, doi:10.1038/nature13376. 
Ridolfi, L., D'Odorico, P., Porporato, A., Rodriguez-Iturbe, I., 2000a. Duration and frequency of water stress in vegetation: An analytical model. Water Resources Research 36, $2297-2307$.

Ridolfi, L., D'Odorico, P., Porporato, A., Rodriguez-Iturbe, I., 2000b. Impact of climate variability on the vegetation water stress. Journal of Geophysical Research-Atmospheres 105, 18013-18025.

Robinson, D., Lebron, I., Ryel, R., Jones, S., 2010. Soil Water Repellency: A Method of Soil Moisture Sequestration in Pinyon-Juniper Woodland. Soil Science Society of America Journal 74, 624-634, doi:10.2136/sssaj2009.0208.

Rodriguez-Iturbe, I., Porporato, A., 2004. Ecohydrology of water-controlled ecosystems: Soil moisture and plant dynamics. Cambridge University Press, London.

Romme, W. H., Allen, C. D., Balley, J. D., Baker, W. L., Bestelmeyer, B. T., Brown, P. M., Eisenhart, K. S., Floyd, M. L., Huffman, D. W., Jacobs, B. F., Miller, R. F., Muldavin, E. H., Swetnam, T. W., Tausch, R. J., Weisberg, P. J., 2009. Historical and Modern Disturbance Regimes, Stand Structures, and Landscape Dynamics in Pinon-Juniper Vegetation of the Western United States. Rangeland Ecology \& Management 62, 203-222, doi:10.2111/08-188R1.1.

Royer, P. D., Breshears, D. D., Zou, C. B., Villegas, J. C., Cobb, N. S., Kurc, S. A., 2012. Density-Dependent Ecohydrological Effects of Pinon-Juniper Woody Canopy Cover on Soil Microclimate and Potential Soil Evaporation. Rangeland Ecology \& Management 65, 11-20, doi:10.2111/REM-D-11-00007.1.

Ryu, Y., Baldocchi, D. D., Ma, S., Hehn, T., 2008. Interannual variability of evapotranspiration and energy exchange over an annual grassland in California. Journal of Geophysical Research - Atmospheres 113, doi:10.1029/2007JD009263.

Sala, O., Golluscio, R., WK, L., Roset, P., 2012. Contrasting nurient-capture strategies in 
shrubs and grasses of a Patagonian arid ecosystem. Journal of Arid Environments 82, 130-135,doi:10.1016/j.jaridenv.2012.02.015.

Schwartz, M., Ahas, R., Aasa, A., 2006. Onset of spring starting earlier across the Northern Hemisphere. Global Change Biology 12, 343-351, doi:10.1111/j.1365-2486.2005.01097.x.

Schwartz, M., Reiter, B., 2000. Changes in North American spring. International Journal of Climatology 20, 929-932, doi:10.1002/1097-0088(20000630)20:8.

Seager, R., Ting, M., Held, I., Kushnir, Y., Lu, J., Vecchi, G., Huang, H., Harnik, N., Leetmaa, A., Lau, N., Li, C., Velez, J., Naik, N., 2007. Model projections of an imminent transition to a more arid climate in southwestern North America. Science 316, 1181-1184, doi:10.1126/science.1139601.

Seager, R., Vecchi, G., 2010. Greenhouse warming and the 21st century hydroclimate of southwestern North America. PNAS 107, 21277-21282, doi:10.1073/pnas.0910856,107.

Seth, A., Rauscher, S., Rojas, M., Giannini, A., Camargo, S., 2011. Enhanced spring convective barrier for monsoons in a warmer world? Climatic Change 104, 403-414, doi:10.1007/s10584-010-9973-8.

Shaw, J., Steed, B., DeBlander, L., 2005. Forest Inventory and Analysis (FIA) annual inventory answers the question: What is happening to pinyon-juniper woodlands? Journal of Forestry 103, 280-285.

United States Department of Agriculture, N. R. C. S., 2013. Web Soil Survey, URL http://websoilsurvey.sc.egov.usda.gov/App/HomePage.htm.

Vargas, R., Collins, S. L., Thomey, M. L., Johnson, J. E., Brown, R. F., Natvig, D. O., Friggens, M. T., 2012. Precipitation variability and fire influence the temporal dynamics of soil CO2 efflux in an arid grassland. Global Change Biology 18, 1401-1411, doi:10.1111/j.1365-2486.2011.02628.x. 
Weiss, J., Gutzler, D., Allred Coonrod, J., Dahm, C., 2004a. Long-term vegetation monitoring with NDVI in a diverse semi-arid setting, central New Mexico, USA. Journal of Arid Environments 58, 249-272, doi:10.1016/j.jaridenv.2003.07.001.

Weiss, J., Gutzler, D., Allred Coonrod, J., Dahm, C., 2004b. Seasonal and inter-annual relationships between vegetation and climate in central New Mexico, USA. Journal of Arid Environments 57, 507-534, doi:10.1016/S0140-1963(03)00113-7.

Weltzin, J., Loik, M., Schwinning, S., Williams, D., Fay, P., Haddad, B., Harte, J., Huxman, T., Knapp, A., Lin, G., Pockman, W., Shaw, M., Small, E., Smith, M., Smith, S., Tissue, D., Zak, J., 2003. Assessing the response of terrestrial ecosystems to potential changes in precipitation. Bioscience 53, 941-952, doi:10.1641/00063568(2003)053[0941:ATROTE]2.0.CO;2.

Williams, A. P., Allen, C. D., Macalady, A. K., Griffin, D., Woodhouse, C. A., Meko, D. M., Swetnam, T. W., Rauscher, S. A., Seager, R., Grissino-Mayer, H. D., Dean, J. S., Cook, E. R., Gangodagamage, C., Cai, M., McDowell, N. G., 2013. Temperature as a potent driver of regional forest drought stress and tree mortality. Nature Climate Change 3, 292-297, doi:10.1038/NCLIMATE1693.

Williams, D., Ehleringer, J., 2000. Intra- and interspecific variation for summer precipitation use in pinyon-juniper woodlands. Ecological Monographs 70, 517-537, doi:10.1890/00129615(2000)070[0517:IAIVFS]2.0.CO;2.

Yu, F., Price, K., Ellis, J., Shi, P., 2003. Response of seasonal vegetation development to climatic variations in eastern central Asia. Remote Sensing of Environment 87, 42-54, doi:10.1016/S0034-4257(03)00144-5. 